Karen Grierson

\section{Department for Business, Enterprise \& Regulatory Reform}

Andrew Allen

\section{Office for National Statistics}

\section{SUMMARY}

A new National Statistics series was published on 28 November 2008 by the Office for National Statistics (ONS), providing data on business births, deaths and survival rates, called Business Demography: Enterprise Births and Deaths. The Department for Business, Enterprise \& Regulatory Reform (BERR) also published its series Business startups and closures: VAT registrations and de-registrations in 2007 on the same day. The year 2008 is the final update to the BERR series; from 2009, users will be directed to the new, more comprehensive, ONS statistics for information on business births, deaths and survival rates. This article explains the key methodological differences between the new series and the existing BERR National Statistic.

\title{
Introducing the new business demography statistics
}

$\Lambda$ new European Commission Structural Business Statistics Regulation came into force in February 2008, requiring National Statistical Institutes to produce statistics on business births, deaths and survival rates. These statistics will be produced using common definitions and methodology, which will ensure greater comparability across the EU. ${ }^{1}$ The new Office for National Statistics (ONS) Business Demography: Enterprise Births and Deaths publication was released for the first time on 28 November 2008, using this common methodology. The Department for Business, Enterprise \& Regulatory Reform (BERR) National Statistics publication Business start-ups and closures: VAT registrations and de-registrations was released for the final time on the same day.

In summary, the key difference between the BERR statistics and the new ONS business demography publication is the inclusion of PAYE-registered units. ${ }^{2}$ Therefore, the new statistics will additionally include the births and deaths of employing businesses, which are not VATregistered, providing a more comprehensive view of business start-up activity.

\section{Comparison of trends in ONS business demography and BERR business start-ups and closures series}

Overall, the ONS business demography series shows higher numbers of business births and deaths than the BERR VATbased statistics (Figure 1). The main reason for the difference is the inclusion of PAYE-registered enterprises in the business demography series, which means that, for the first time, businesses with employees who are not registered for VAT will be included in the enterprise births and deaths series. A full description of the differences between the two series is included later.

The same pattern is observed in the rates of enterprise birth and death (Figure 2). The ONS enterprise birth rate (as a proportion of active enterprises) was 13.1 per cent in 2007,

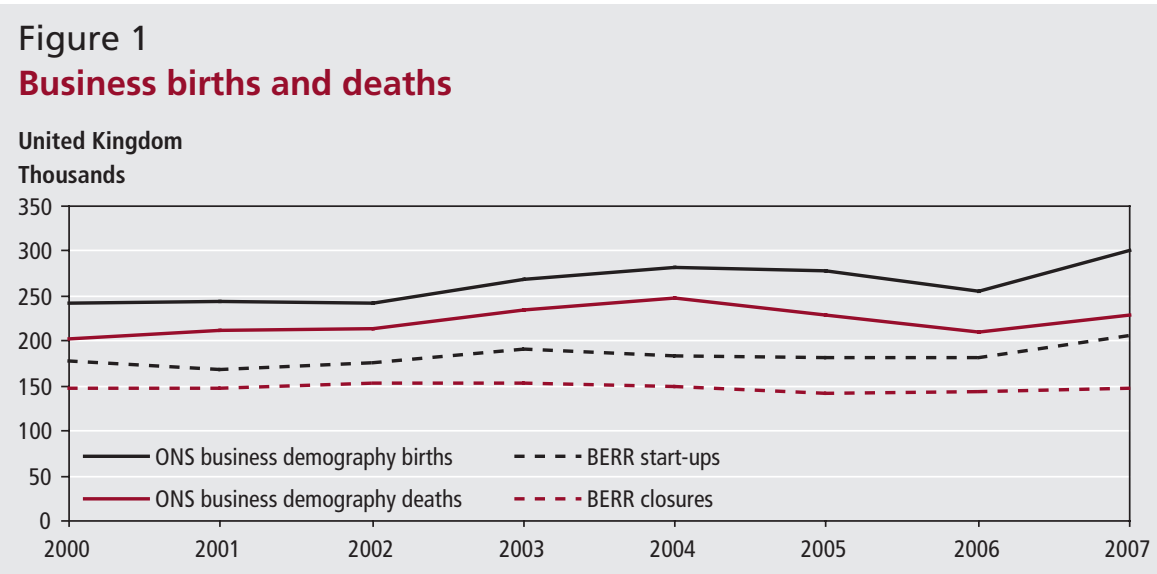


compared with 10.1 per cent in the BERR VAT-based series. The ONS enterprise death rate (as a proportion of active enterprises) was 9.9 per cent in 2007, compared with 7.3 per cent in the BERR VAT-based series.

It is also noticeable that, although the volume and rate of births and deaths in both series follow broadly the same trend, there appears to be a small difference between the series in the timing of the peaks, which occur slightly earlier in the BERR series.

While there are differences between the volumes and rates in the two series, both the ONS and BERR publications show the highest birth and death rates to be in London and the lowest rates to be in Northern Ireland (Table 1).

The differences observed in these comparison tables and charts in the levels of births and deaths are attributable to the reasons outlined in Table 2. It is not possible to decompose the difference into these categories, but the largest contribution to the difference is caused by the inclusion of PAYE-based enterprises in the business demography publication.

\section{ONS business demography methodology}

A joint Eurostat/OECD Manual on Business Demography has been produced which defines and sets out the broad methodology that should be used to produce business demography data.

The starting point for demography is the concept of a population of active businesses in a reference year. These are defined as businesses that had either turnover or employment at any time during the reference period. Births and deaths are then identified by comparing active populations for different years.

\section{Births}

A birth is defined as a business that was present in year $t$, but did not exist in year $\mathrm{t}-1$ or $\mathrm{t}-2$. Births are identified by making a comparison of annual active population files and identifying those present in the latest file, but not the two previous ones.

Births do not include entry into the population as a result of mergers, breakups, split-offs or other restructuring.

\section{Deaths}

A death is defined as a business that was on the active file in year $t$ but was no longer present on the active file in year $t+1$ or $t+2$. In order to produce more timely statistics, the UK method diverges from the Eurostat manual at this point. The Eurostat manual requires a check to be made against the two years following a death to identify and remove any reactivations (that is, following the Eurostat methodology would mean a

\section{Figure 2}

Business birth and death rates ${ }^{1}$

United Kingdom
Percentages

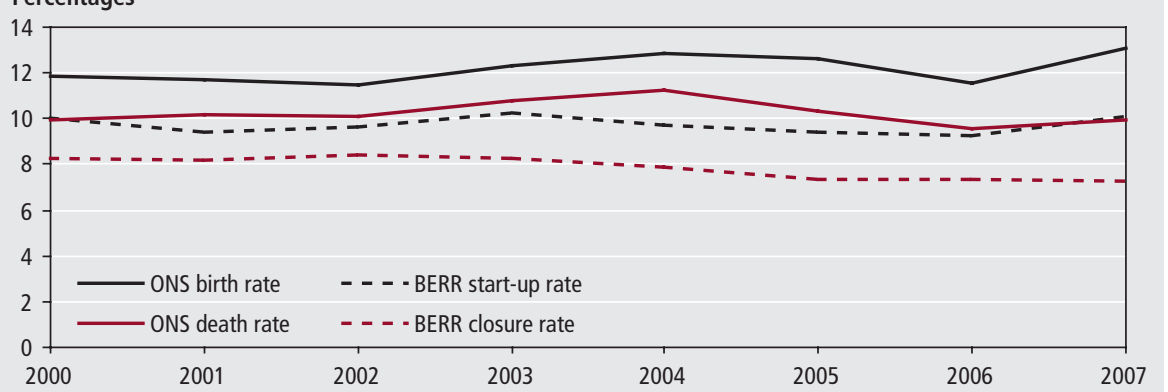

Note:

1 These are calculated as births or deaths as a proportion of the active stock of enterprises in each year.

\section{Table 1}

\section{Business births and deaths: by region}

ONS Business Demography: Enterprise Births and Deaths

\begin{tabular}{|c|c|c|c|c|c|}
\hline & \multicolumn{3}{|c|}{ Births 2007} & \multicolumn{2}{|c|}{ Deaths 2007} \\
\hline & $\begin{array}{l}\text { Active } 2007 \\
\text { (thousands) }\end{array}$ & $\begin{array}{r}\text { Number } \\
\text { of births } \\
\text { (thousands) }\end{array}$ & $\begin{array}{l}\text { Birth rate } \\
\text { (per cent) }\end{array}$ & $\begin{array}{r}\text { Number } \\
\text { of deaths } \\
\text { (thousands) }\end{array}$ & $\begin{array}{r}\text { Death rate } \\
\text { (per cent) }\end{array}$ \\
\hline North East & 62.3 & 9.0 & 14.5 & 6.0 & 9.6 \\
\hline North West & 232.9 & 31.4 & 13.5 & 23.6 & 10.1 \\
\hline Yorkshire and The Humber & 166.4 & 21.2 & 12.7 & 17.0 & 10.2 \\
\hline East Midlands & 157.3 & 19.2 & 12.2 & 14.9 & 9.5 \\
\hline West Midlands & 191.4 & 24.0 & 12.6 & 19.2 & 10.0 \\
\hline East of England & 233.4 & 28.8 & 12.3 & 22.2 & 9.5 \\
\hline London & 388.6 & 63.9 & 16.5 & 45.7 & 11.8 \\
\hline South East & 369.2 & 44.9 & 12.1 & 35.5 & 9.6 \\
\hline South West & 205.6 & 23.7 & 11.5 & 19.0 & 9.2 \\
\hline Wales & 91.0 & 10.1 & 11.1 & 8.7 & 9.5 \\
\hline Scotland & 145.4 & 19.3 & 13.3 & 12.4 & 8.5 \\
\hline Northern Ireland & 57.7 & 6.0 & 10.3 & 4.0 & 6.9 \\
\hline Total & $2,301.2$ & 301.6 & 13.1 & 228.2 & 9.9 \\
\hline
\end{tabular}

BERR Business start-ups and closures: VAT registrations and de-registrations

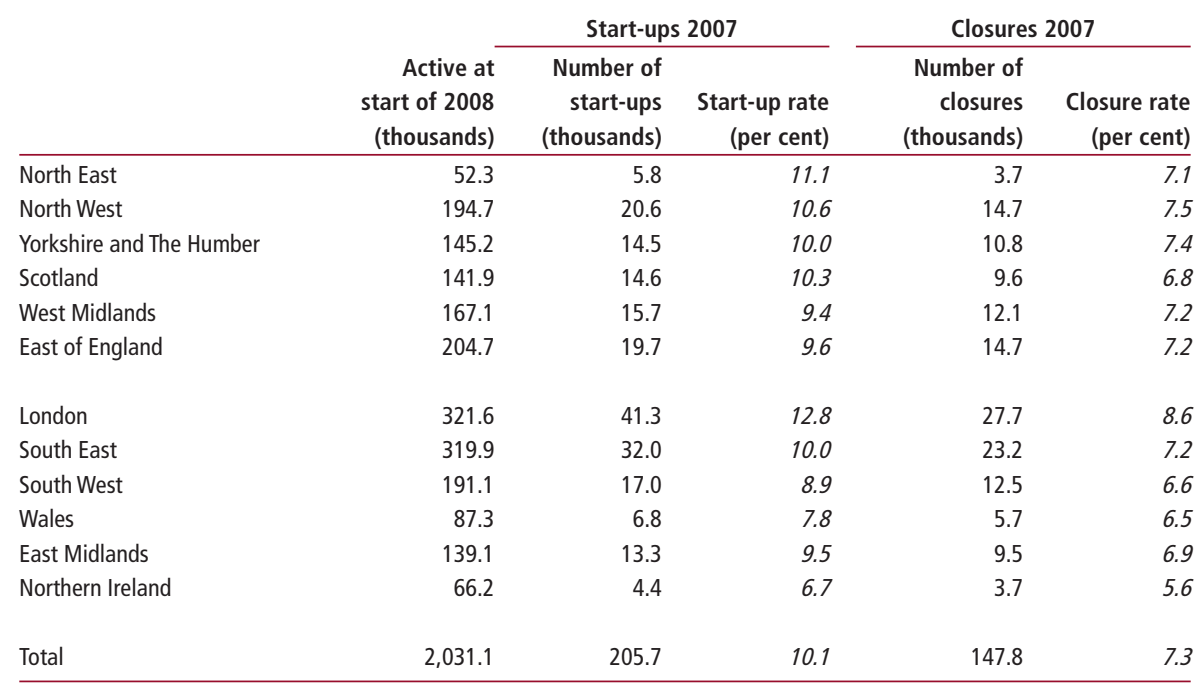

delay of up to three years to allow checks to be made before publishing business death data). The UK business demography publication contains a preliminary death indicator, which includes an adjustment for estimated reactivations. This estimate is subject to revision. Inclusion of this adjustment allows UK users access to more timely data. 
Table 2

Key methodological differences between main business population publications

\begin{tabular}{|c|c|c|c|}
\hline & $\begin{array}{l}\text { ONS Business Demography: } \\
\text { Enterprise Births and Deaths }\end{array}$ & $\begin{array}{l}\text { BERR Business start-ups and closures: } \\
\text { VAT registrations and de-registrations }\end{array}$ & $\begin{array}{l}\text { ONS UK Business: } \\
\text { Activity, Size and Location }\end{array}$ \\
\hline Coverage & VAT- and/or PAYE-registered businesses & VAT-registered businesses only & $\begin{array}{l}\text { VAT- and/or PAYE-registered businesses (from } 2008 \\
\text { onwards) excluding unmatched non-corporate PAYE } \\
\text { businesses }\end{array}$ \\
\hline Stock & $\begin{array}{l}\text { Recognises activity occurring at any point during the } \\
\text { year }\end{array}$ & Live units at a point in time & Live units at a point in time \\
\hline Timeliness & $\begin{array}{l}\text { Annual publication: first publication with } 2007 \text { data } \\
\text { published on } 28 \text { November } 2008\end{array}$ & $\begin{array}{l}\text { Annual publication: final publication with } 2007 \text { data } \\
\text { published on } 28 \text { November } 2008\end{array}$ & $\begin{array}{l}\text { Annual publication: } 2008 \text { data published in September } \\
2008\end{array}$ \\
\hline Geography & $\begin{array}{l}\text { UK with country, region, unitary authority, county and } \\
\text { district breakdowns }\end{array}$ & $\begin{array}{l}\text { UK - including regional, local authority and } \\
\text { parliamentary constituency breakdowns }\end{array}$ & $\begin{array}{l}\text { UK - including regional, local authority and } \\
\text { parliamentary constituency breakdowns }\end{array}$ \\
\hline Legal status & $\begin{array}{l}\text { Company, sole proprietor, partnership, public } \\
\text { corporation and non-profit organisations }\end{array}$ & All & All \\
\hline Industry & $\begin{array}{l}\text { SIC 2003, excluding agriculture (divisions } 01,02 \text { and } \\
\text { 05), holding companies (SIC class 7415) and public } \\
\text { administration (division 75) }\end{array}$ & $\begin{array}{l}\text { SIC } 2003 \text { divisions } 01-93 \text { (private households and } \\
\text { extra-territorial activities excluded) }\end{array}$ & SIC 2003 divisions 01-99 \\
\hline Exclusions & $\begin{array}{l}\text { Excludes managed service companies, although these } \\
\text { are included in the data published by Eurostat }\end{array}$ & $\begin{array}{l}\text { Excludes managed service companies and official } \\
\text { receivers }\end{array}$ & Excludes managed service companies \\
\hline Adjustments & $\begin{array}{l}\text { Adjustments are made to the latest two years' deaths } \\
\text { to allow for re-activations (see section on deaths for } \\
\text { more detail) }\end{array}$ & $\begin{array}{l}\text { Registrations and deregistrations are adjusted (back } \\
\text { to 1996) to produce estimates of the final volume } \\
\text { of start-ups and closures once late registrations and } \\
\text { deregistrations have been received or reactivations } \\
\text { have occurred }\end{array}$ & None \\
\hline
\end{tabular}

Reactivations occur where a business becomes dormant for a period of less than two years, then recommences activity in a manner which complies with a definition of continuity. If the definition of continuity is not met, for example, when a business recommences activity but at a different location and with a different activity, this would be considered as a death followed by a birth. There are a number of reasons why a business may be dormant for a period reflecting the underlying administrative processes.

Reactivations also occur due to lags in the administrative sources (VAT/PAYE), which mean it is possible that a business which is continuing to trade can appear to die on the Inter-departmental Business Register (IDBR). If an existing VAT scheme is deregistered, and there is a delay in the birthing and/or matching of the new VAT scheme, it can leave the enterprise without a live administrative source, which will result in it being assumed dead. Additionally, VAT-based businesses where turnover drops to zero are automatically assumed to be dead on the IDBR, but will rebirth if turnover is then reported in a later period.

The deaths data exclude losses to the population as a result of mergers, breakups, split-offs or other restructuring.

\section{Survivals}

A business is deemed to have survived if, having been a birth in year $t$ or having survived to year $t$, it is active in terms of employment and/or turnover in any part of year $t+1$. A business is considered to have survived if it is active in any part of the survival year under consideration. Survival data are presented for businesses that have survived for up to five years.
It is important to note that a business active in year $t$ could also have been a birth in year $t$.

\section{Comparison of methodological differences}

Table 2 outlines the key methodological differences between the new ONS business demography publication, the existing BERR business start-ups and closures statistics and, for completeness, the other ONS publication relating to the business stock UK Business: Activity, Size and Location.

The main difference between the ONS business demography and the BERR VATbased publication is the inclusion of PAYEonly records. Therefore, for the first time, businesses with employees who are not registered for VAT will be included in the enterprise births and deaths series.

The new business demography data set also has a higher number of active businesses than both the BERR VAT-based series and the expanded UK Business: Activity Size and Location publication. This is because the business demography methodology takes into account businesses that were active at any time during the reference year, whereas the BERR series calculates stock by adding registrations and subtracting deregistrations from the previous year's stock; the $U K$ Business: Activity Size and Location publication is based on a snapshot taken from the IDBR at a point in time in March.

Additionally, business demography includes a group of non-corporate PAYE businesses, which are excluded from UK Business: Activity, Size and Location due to a small risk of duplication. The scope of this publication will be reviewed and may be broadened to include these businesses in the next year.

\section{Notes}

1 For full details of the methodology, see Eurostat-OECD Manual on Business Demography Statistics 2007 at www.oecd.org/document/34/ 0,3343,en_2649_34233_39913698_1_1_ 1_1,00.html

2 The existing BERR Business start-up and closures: VAT registrations and de-registrations publication identifies births through their VAT registration, but they can remain in the survival population if they cease to be VAT registered, but have an active PAYE registration. But, for practical purposes, the publication was described in terms of VAT registrations.

\section{CONTACT}

(凶)elmr@ons.gsi.gov.uk

\section{REFERENCES}

Department for Business, Enterprise \& Regulatory Reform (2008) Business start-ups and closures: VAT registrations and de-registrations 2007 at http://stats.berr.gov.uk/UKSA/ed/ sa20081128.htm

Office for National Statistics Business Demography: Enterprise Births and Deaths at www.statistics.gov.uk/statbase/product. asp?vInk=15186 